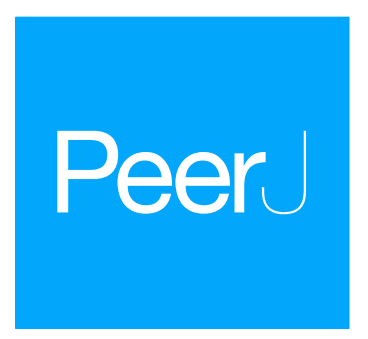

Submitted 7 November 2018

Accepted 17 March 2019

Published 15 May 2019

Corresponding author

Hilmar Hinz,

hhinz@imedea.uib-csic.es

Academic editor

Isabel Sousa Pinto

Additional Information and Declarations can be found on page 20

DOI 10.7717/peerj.6797

Copyright

2019 Hinz et al.

Distributed under

Creative Commons CC-BY 4.0

OPEN ACCESS

\section{Fish nursery value of algae habitats in temperate coastal reefs}

\author{
Hilmar Hinz ${ }^{1,2}$, Olga Reñones ${ }^{2}$, Adam Gouraguine ${ }^{3}$, Andrew F. Johnson ${ }^{4}$ and \\ Joan Moranta ${ }^{2}$ \\ ${ }^{1}$ Instituto Mediterraneo de Estudios Avanzados (IMEDEA; CSIC-UIB), Esporles, Illes Balears, Spain \\ ${ }^{2}$ Instituto Español de Oceanografía (IEO), Centre Oceanográfic de les Balears, Ecosystem Oceanography Group \\ (GRECO), Palma, Illes Balears, Spain \\ ${ }^{3}$ School of Biological Sciences, University of Essex, Colchester, United Kingdom \\ ${ }^{4}$ MarFishEco, Portland, OR, United States of America
}

\section{ABSTRACT}

The nursery function of coastal habitats is one of the most frequently mentioned and recognized ecosystem services in the valuation of coastal ecosystems. Despite its importance our understanding of the precise habitat parameters and mechanisms that make a habitat important as a nursery area is still limited for many species. The study aimed to establish the importance of different algae morphotypes in providing shelter and food for juvenile coastal fish during the main settlement peaks, in early spring and late summer, in littoral rocky reef systems in the Northwestern Mediterranean. The results of our study showed strong seasonal differences in algae cover, composition and height between the two sampling periods. Overall, during spring the algae were well developed, while in late summer, both density and height, of most algae decreased considerably. Equally, prey biomass, in form of suitable sized invertebrate fauna associated to the algae, decreased. Accordingly, the shelter and food for the fish settling in this habitat during late summer were less abundant, indicating a mismatch between the observed presence of juvenile fish and optimal habitat conditions. Differences in prey densities were detected between algae morphotypes, with structurally more complex algae, such as Cystoseira spp. and Halopteris spp. consistently containing more prey, independent of season, compared to simpler structured morphotypes such as Dictoytales. The study furthermore related juvenile fish density to habitats dominated by different algae morphotypes. Out of the three-study species (Diplodus vulgaris, Symphodus ocellatus, Coris julis) only S. ocellatus showed a significant association with an algae habitat. S. ocellatus related positively to habitats dominated by Dictoytales which provided the highest cover during late summer but had the lowest prey densities. A strong association of this species with Cystoseira, as reported by other studies, could not be confirmed. Cystoseira was abundant within the study area but in a state of dieback, showing loss and reduced height of foliage, typical for the time of year within the study area. It is therefore likely that algae-fish associations are context-dependent and that several algae species may fulfil similar functions. We also discovered that prey biomass did not appear to have an important effect on juvenile abundances. Nevertheless, the availability of prey may influence juvenile fish condition, growth performance and ultimately long-term survival. We therefore suggest that future studies on habitat quality should also include, besides abundance, indicators related to the condition and growth of juveniles. 
Subjects Conservation Biology, Ecology, Marine Biology

Keywords Juvenile fish, Match/mismatch theory, Benthic prey, Habitat complexity, Cystoseira, Macroalgae, Labridae, Nursery areas, Dictoytales, Rocky reefs

\section{INTRODUCTION}

The provision and value of nursery habitats by the coastal zone is one of the most frequently mentioned and recognized ecosystem services in the valuation of coastal marine ecosystems (Duarte, 2000; Jackson et al., 2001; Jackson et al., 2015). As many coastal habitats are under increasing human pressures from urbanisation, fishing, climatic change and the introduction of alien species (Sala et al., 2011; Sala et al., 2012; Vergés et al., 2014a; Vergés et al., 2014b), the provisioning of this ecosystem service is progressively also under threat. While the large-scale importance of nursery habitats for ecosystem functioning, food production and integrity of ecosystems is recognized, a detailed understanding over which habitat types constitute to this function is still lacking (Beck et al., 2001). Seagrass meadows and estuarine systems have been the focus of marine nursery habitat research (e.g., Heck, Hays \& Orth, 2003; Seitz et al., 2013; Woodland et al., 2012; Ruiz-Frau et al., 2017), while studies that focus on littoral rocky reef systems appear less frequently in the literature (but see Cheminée et al., 2017; Guidetti, 2000; Harmelin-Vivien, Harmelin \& Leboulleux, 1995). Although spatially less extensive compared to seagrass meadows, littoral rocky reef systems harbour a wide variety of different algae species, providing shelter and food, in the form of associated fauna, to juvenile fish (Harmelin-Vivien, Harmelin \& Leboulleux, 1995; Cheminée et al., 2013; Félix-Hackradt et al., 2014).

In the Mediterranean, littoral rocky reef habitats are used by a variety of commercial and non-commercial species for part, or their entire life cycle (Harmelin-Vivien, Harmelin \& Leboulleux, 1995; Guidetti, 2000; La Mesa et al., 2011; Félix-Hackradt et al., 2014; Cheminée et al., 2017). In general, coastal species with smaller body sizes, such as many Labridae, Blenniidae and Gobiidae, complete their entire life cycle within this habitat. Several other, larger, commercial species, such as various Sparid species e.g., Pagelus spp or Dentex dentex, often only use it as a nursery habitat, with the larger juvenile and adult life stages moving further offshore. Settlement of juvenile fishes in rocky littoral habitats occurs throughout the year but most species have a settlement peak between early spring and late summer (Garcia-Rubies \& Macpherson, 1995; Biagi, Gambaccini \& Zazzetta, 1998; Bussotti $\&$ Guidetti, 2011). The survival of recently settled juveniles within a habitat, through to their recruitment to the adult population, depends to a large extent on the environmental conditions encountered at the site of settlement (Beck et al., 2001). Intolerance to physical extremes, starvation and predation are among the major causes of juvenile mortality in these habitats (Sogard, 1997; Guidetti, 2001; Thiriet et al., 2016; Cuadros et al., 2018). High nursery value is thus conferred through a combination of factors that provide adequate physical conditions, refuge space and a sufficient food supply. Highly structured habitats are thought to provide both, shelter and an abundance of food, that may facilitate juvenile survival and growth and thus contribute to overall production and population stability (Cheminée et al., 2016; Dahlgren \& Eggleston, 2014; Leslie et al., 2017; Parsons et al., 2015; 
Scharf, Manderson \& Fabrizio, 2006). Although the importance of habitat complexity is well documented, it should be noted that it is likely to be context-dependent related to spatial scale and species-specific habitat requirements. For example, highly complex habitats have also been reported to negatively affect juvenile fish, by reducing feeding efficiency (Tátrai $\&$ Herzig, 1995) and increasing mortality through the harbouring of ambush predators (Canion \& Heck, 2009).

Nursery habitats that hold large numbers of juvenile fish are important to ensure future recruitment into adult populations. They also contribute to the maintenance of essential food web links and energy transfer processes within many coastal systems (Gee, 1989; Schückel et al., 2013; Tito de Morais \& Bodiou, 1984), consuming the micro-fauna (mesograzers e.g., micro crustaceans such as Harpacticoids, Isopods and Amphipods) associated with macroalgae and seagrasses (Bologna \& Heck, 2002; Jaschinski \& Sommer, 2008; Vázquez-Luis, Sanchez-Jerez \& Bayle-Sempere, 2008). Macrophytes often have morphological or chemical deterrents that inhibit direct herbivory by larger consumers, such as fish and urchins (Cruz-Rivera \& Villareal, 2006). Therefore, meso-grazers that can directly utilize macrophytes are thought to represent an important link in the energy transfer between macroalgae and fish (Lewis \& Anderson, 2000; Duffy \& Hay, 2000). Many juveniles are also, in turn, consumed by larger higher trophic level predators (Doherty \& Sale, 1986; Sogard, 1997), thus representing the intermediate stage of energy transfer from primary producers to higher trophic level fish.

Perennial algae species belonging to the genus Cystoseira (Fucales, Phaeophyceae) are thought to represent habitats of high quality for juvenile coastal fish in the Mediterranean (Ruitton, Francour \& Boudouresque, 2000; Sala et al., 2012; Cheminée et al., 2013). Cystoseira are macrophytes with a tree-like morphology that can form dense meadows over rocky substrates, aggregations of which are often referred to as Cystoseira forests. This habitat generally shows high primary productivity, is morphologically highly complex and harbours a diverse invertebrate and fish fauna. Therefore, Cystoseira forests, in addition to the seagrasses, have been recognised as a central foundation species (as defined by Dayton, 1972) of the euphotic zone in the Mediterranean (Irving et al., 2009; Vergés, Alcoverro \& Ballesteros, 2009). Past declines of subtidal Cystoseira forests (Thibaut et al., 2005; Sala et al., 2012) may have had a negative effect on the fish nursery value of coastal rocky reef habitats in many regions of the Mediterranean. Nevertheless, the role and importance of other macroalgae-dominated habitats for juvenile fish has not been fully explored and these could also provide adequate shelter and food for juvenile fish. Thus far, the services or functions that littoral macroalgae may provide to juvenile fish, i.e., shelter and food, have been suggested and only partially tested and quantified scientifically (Sala \& Ballesteros, 1997; Ruitton, Francour \& Boudouresque, 2000; Cheminée et al., 2013). Thus, overall, we know little about the real habitat value of the littoral macroalgae and the consequences their loss has on the functioning of coastal ecosystems as fish nursery habitats. Furthermore, we are still unaware if there may be other macroalgae habitats, equivalent to Cystoseira forests, that may provide a similar function and compensate for their loss. Such knowledge will be of importance for the development of management and conservation strategies against the backdrop of the currently observed acute environmental 
change experienced in coastal rocky shores in the Mediterranean, due to chronic pollution, urbanisation, fishing and the introduction of non-native macroalgae species (Sala et al., 2012) and herbivorous fish (Sala et al., 2011; Vergés et al., 2014a) that have the potential to rapidly modify coastal habitats.

The present study aims to quantify the importance of the Mediterranean littoral habitats of varying algal morphotype composition, with respect to its functions for commonly occurring juvenile fish. In particular, the study focused on measuring habitat parameters related to the key habitat requirements for juveniles, i.e., shelter and food. Prey availability in macroalgae has generally been inferred by past studies on nursery habitat quality in the Mediterranean (Cheminée et al., 2013; Cheminée et al., 2017), but thus far has not been quantified for different algae morphotypes. The study examined the relationship between juvenile density and physical and biological habitat parameters, over two distinct settlement periods (Spring and late Summer) and geographical areas (Mallorca and Menorca). Sampling on these two neighbouring islands was conducted to investigate the generality of any findings within the context of the Balearic Islands. The algae habitats sampled included areas dominated by Cystoseira forest and therefore provided the opportunity to contrast this habitat type, with respect to its nursery value, with habitats dominated by other macroalgae. Against the background of rapidly changing algae habitats in the Mediterranean this study aimed to contribute in understanding if a loss of Cystoseira habitats will disproportionally affect the nursery function of littoral habitats or if other algae could provide similar functions.

\section{METHODS}

\section{Fish study species}

The study focused on three common and abundant fish species of littoral rocky reefs in the Mediterranean: Diplodus vulgaris (common two-banded seabream), Symphodus ocellatus (ocellated wrasse), Coris julis (Mediterranean rainbow wrasse). These species were chosen as they occurred at sufficiently high abundances to engage with the posed research questions. Settlement of the two-banded seabream, occurs in very shallow rocky coastal areas and seagrass meadows but are thought to migrate quickly to deeper waters following settlement (Harmelin-Vivien, Harmelin \& Leboulleux, 1995). Settlement peaks for this species have also been reported to occur in two settlement pulses, one in early November and the other in January-through to March (Vigliolat et al., 1998; García-Rubies \& Macpherson, 1995; Harmelin-Vivien et al., 1985). Biagi, Gambaccini \& Zazzetta (1998) describes the settlement periods to occur in December-January and March. Within the Balearic Islands, the authors observed the presence of recently settled juveniles in early spring (April-May).

The settlement period of the two wrasse species has been reported to occur during late summer between July to August (García-Rubies \& Macpherson, 1995; Biagi, Gambaccini \& Zazzetta, 1998; Bussotti \& Guidetti, 2011) while Raventós (2006) reports settlement of S. ocellatus slightly earlier from June to mid-July. Within the present study, the presence of recently settled juveniles was observed at the end of August by the authors. The two species of wrasse have been reported to settle predominantly in rocky habitats with high algal 
cover (García-Rubies \& Macpherson, 1995; Biagi, Gambaccini \& Zazzetta, 1998; Bussotti \& Guidetti, 2011; Félix-Hackradt et al., 2014). Juveniles of D. vulgaris have been reported to feed predominantly on micro-crustaceans (Altin et al., 2015). Adults of S. ocellatus feed predominantly on small crustaceans and molluscs with a suspected tendency towards herbivory (Kabasakal, 2001) and adult C. julis feed on gastropods, sea urchins and small crustaceans (Sinopoli et al., 2016). Presently there is no information on the diet of the juvenile stages of these two wrasse species.

\section{Study area and sampling design}

Littoral habitats were studied in the Balearic Archipelago, in the western Mediterranean. Surveys were conducted in early spring (April-May) and late summer (August-September) of 2014, on the islands of Mallorca and Menorca. Sampling in Mallorca took place around the northwestern part, while sampling in Menorca was primarily conducted around the western part (see Fig. 1). Sampling at each island and during each period was conducted in 10 consecutive day surveys. The sampling stations comprised rocky reef zones with a depth of 7-10 m. The same depth range was chosen not to introduce any depth related confounding effects. Furthermore, at this depth we encountered extensive algae communities and juvenile fish. From an operational point of view, this depth allowed for comfortable diving and sufficiently long bottom time for surveying. Stations were haphazardly chosen to cover a variety of habitats, including different physical (geomorphology) and biological (algae cover) properties. Eight stations were sampled per sampling period and island.

In Mallorca the linear distance between consecutive stations was on average $4 \mathrm{~km}$ and the survey area extended over a coastal strip of approximately $55 \mathrm{~km}$. In Menorca, the distance between consecutive stations was $7 \mathrm{~km}$ on average and the survey area covered a coastal strip of approximately $75 \mathrm{~km}$. Some of the survey sites were sampled both in spring and late summer, while other sites were only sampled within one season. The overall number of samples was however balanced between the two seasons and islands (see above).

\section{Fish and habitat census}

At each sampling station the fish community and the habitat were assessed by diver underwater visual census. The fish assemblage was assessed in 6 replicates of $15 \times 2 \mathrm{~m}$ transects with a horizontal gap between each of at least $20 \mathrm{~m}$. All fish sighted along the transect were recorded and their size was estimated to the nearest $\mathrm{cm}$ (Harmelin-Vivien et al., 1985). Benthic composition along the transects was characterized using the following categories: sand, pebbles and gravel, seagrass and rock. The habitat complexity of the substrate was also assessed, using a five-point scale index for rugosity, presence of different sized boulders and amount of refuge spaces (see Appendix S1 for field sampling protocol).

Algae cover, composition and height was measured in three haphazardly placed $50 \times$ $50 \mathrm{~cm}$ quadrats along the transect. Quadrats were further subdivided into 25, $10 \times 10$ $\mathrm{cm}$ squares using nylon string. These sub-squares were used to estimate the $\%$ cover of 8 algae morphotypes (Fig. 2) and unvegetated barren patches. If a morphotype occurred in a sub-square, the square was counted. For each morphotype, the total number of squares 


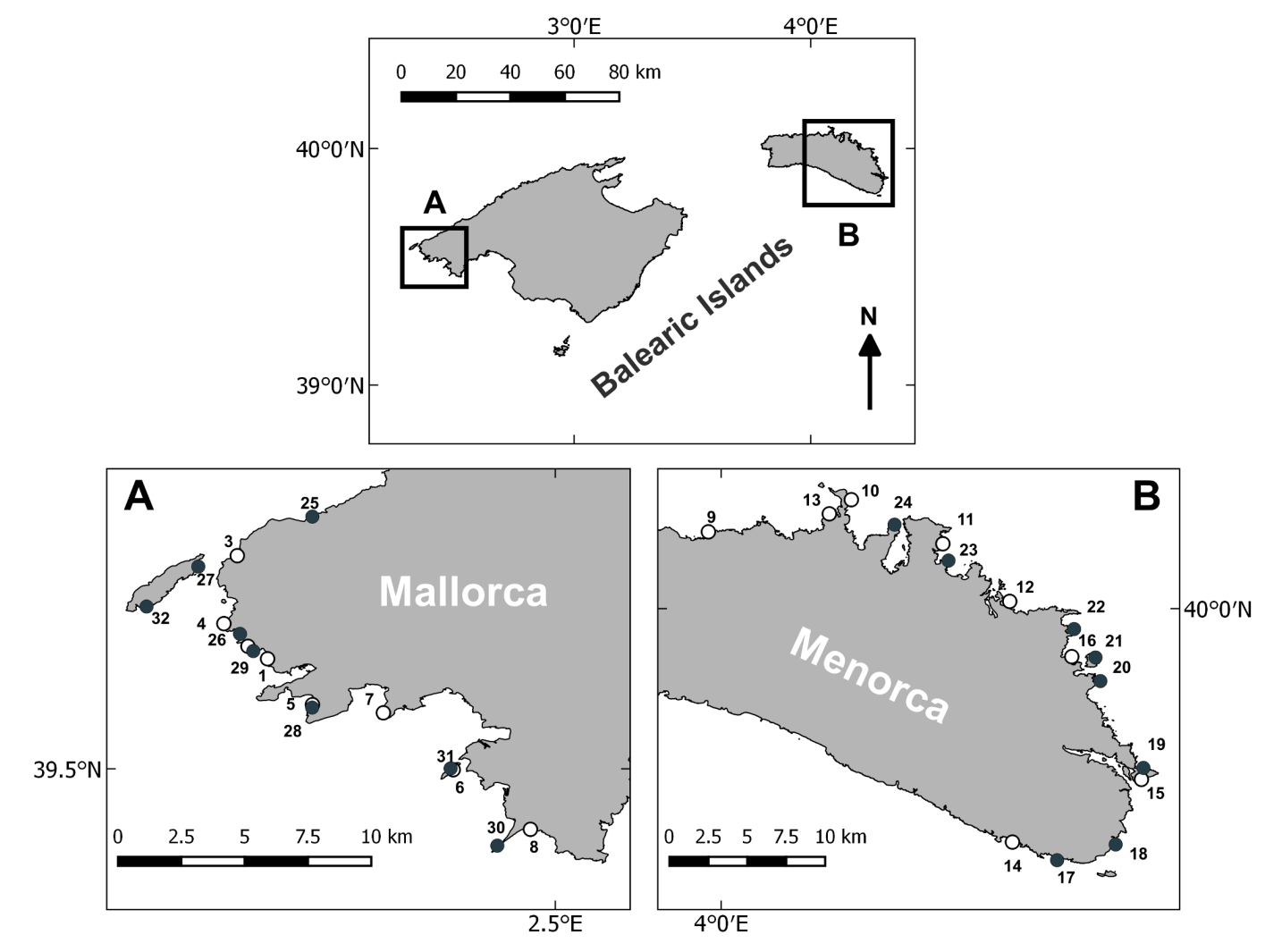

Figure 1 Survey area and sampling locations. Sampling stations surveyed in Mallorca (A) and Menorca (B). White circles denote stations sampled in spring and black circles denote stations sampled during the summer.

Full-size DOI: 10.7717/peerj.6797/fig-1

it occurred in was recorded, as well as their average height in $\mathrm{cm}$ form the rock surface. Algae morphotype cover in $\mathrm{m}^{2}$ within transects was calculated by taking the $\mathrm{m}^{2}$ recoded for rocky reef habitats overgrown by algae (as opposed to being occupied by sand or pebble substratum) and this area was dividing proportionally according to the $\%$ cover of each morphotype obtained by the quadrate samples. The following algae morphotypes represented by various related species that are commonly encountered in the rocky littoral zone were used (Fig. 2): erect tree like 1-ET (Cystoseira spp.), soft leaf like 2-SL (Dictyopteris polypoides and Dictyota spp.), filamentous 3-FI (Dictyota dichotoma var. intricate, Dictyota spp. and occasional Hincksia spp.), tubular 4-TU (Cladostephus spongiosus), plumose 5-PL (Asparagopsis spp.), bulbous tree like 6-BT (Halopteris spp.), leathery bands 7-LB (Padina pavonica), turf forming 8-TF (dominated by Corallinaceae such as Haliption vigatum). For data from dive transect see Dataset S1.

\section{Sampling of algae associated fauna and prey communities}

To determine prey availability for juvenile fish, the associated fauna of dominant macroalgae was sampled for each station. At each site, the three most dominant algae types were sampled by collecting $6 \times 113 \mathrm{~cm}^{2}$ samples. A circular tube of $5 \mathrm{~cm}$ height and $11.5 \mathrm{~cm}$ diameter was used to define the surface area for algae cuttings $\left(0.01 \mathrm{~m}^{2}\right)$. A $0.55 \mu \mathrm{m}$ meshed sampling 


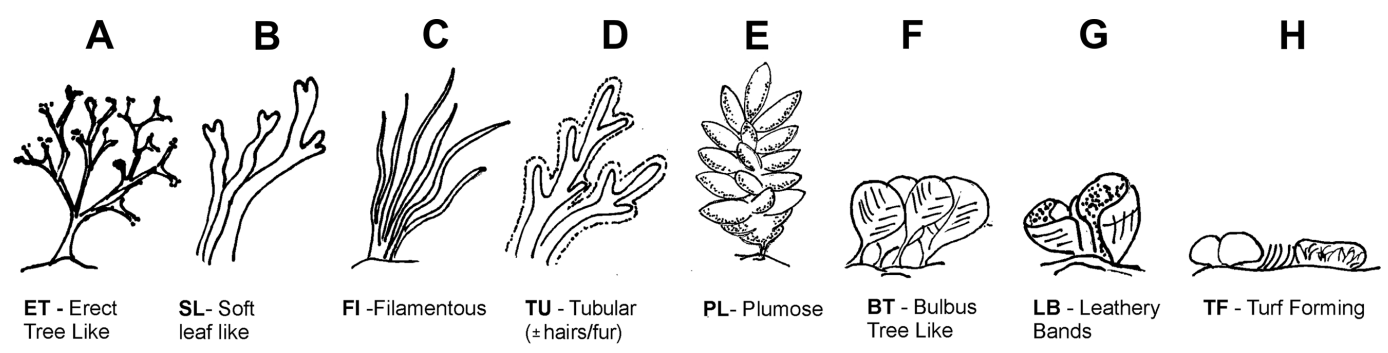

Figure 2 Algae morphotype. Algae morphotypes surveyed along dive transects corresponded to different species complexes with similar morphology (A) Erect tree like (Cystoseira spp.), (B) soft leaf like (Dictyopteris spp. and Dictyota spp.),(C) filamentous Dictyota dichotoma var. intricate, Dictyota spp. and occasional Hincksia spp.), (D) tubular (Cladostephus spongiosus), (E) plumose (Asparagopsis spp.), (F) bulbous tree like (Halopteris spp.), $(\mathrm{G})$ leathery bands (Padina pavonica), $(\mathrm{H})$ turf forming (dominated by Corallinaceae such as Haliption vigatum). Copyright $\mathrm{H}$. Hinz.

bag was draped over the piece of tube to collect algae cuttings and to retain associated fauna. The samples were transferred to plastic bags and stored frozen. Once defrosted, the samples were pooled and rinsed into a receptacle using fresh water. The algae were dryed with kitchen paper and the wet weight recorded from each station. The water from the receptacle was passed through a $300 \mu \mathrm{m}$ mesh sieve and any retained fauna was processed. All large fauna $(>5 \mathrm{~mm}$ ) were preserved in $70 \%$ ethanol. Using a Folsom plankton sample splitter, the remaining sample, was split up to 4 times depending on its overall volume. The final split fraction of the sample was re-sieved over a $300 \mu \mathrm{m}$ mesh and preserved in $70 \%$ ethanol. The number of sample splits was recorded for each faunal sample to later enable calculation of faunal abundance and biomass of the whole sample.

All fauna retained from the samples was sorted into large taxonomic groups (see Appendix S2 for a full list of groups). A photograph was taken of each taxonomic group using a standard digital camera (Canon powershot G7; Canon, Tokyo, Japan) for the large fraction and a digital camera (EC3) attached to a Leica stereo microscope (MZ16; Leica, Wetzlar, Germany) for the small fraction. The photograph served to measure the size of the organisms and to quantify their abundance. Image analysis software, ImageJ (Rueden et al., 2017), was used to measure the size of all organisms using the polyline measurement tool. The pixel length of each measurement line was converted to $\mu \mathrm{m}$ using values attained from calibration images. Length measurements were furthermore converted to biomass using published length-weight relationships of respective taxonomic groups (see Appendix S2 and Dataset S2 for more details on the size-mass conversion and Dataset S3 for data on associated invertebrate fauna size measurements).

Since not all invertebrates collected can be consumed, by juvenile fish, due to their size, stomach content analyses were carried out on a subset of fish. This allowed to determine the taxonomic composition and size of the fauna consumed to more accurately estimate prey densities within algae at each station. Approximately 50 fish of each species were used. These were selected at random, from different stations at which fish samples were available (see protocol of fish sampling below). The taxonomic group and size of taxa were determined from photographs in the same manner as for the determination of algae 
associated fauna. Only prey items that had an intact body outline were measured. For data of prey sizes found in stomachs see S6.

To determine the upper size limit of suitable prey for juveniles of each study species (those below $60 \mathrm{~mm}$ total length) we used quantile regressions analysis (Cade \& Noon, 2003). Only significant upper quantiles were considered, starting from the 95th quantile moving down in steps of 5. Since some invertebrate taxa had an elongated, and others had compact body shape, upper prey size limits for respective prey body shapes were calculated for each fish species. The cutoff point for prey sizes to be considered for the determination of prey availability in algae was the value where the upper quantile regression line intersected with the $60 \mathrm{~mm}$ total length of the study species (i.e., set length of a juvenile fish) (Cade \& Noon, 2003). Furthermore, we only considered prey taxa that cumulatively contributed to at least $90 \%$ of the prey taxa found in stomachs thus excluding rare species that were only occasionally or accidentally been ingested. As not all algae morphotypes were sampled in both islands, the data on the abundance and biomass of prey per algae morphotype were therefore presented using pooled data from both islands for the season in which juvenile fish of respective study species occurred i.e., D. vulgaris spring and summer for C. julis and S. ocellatus.

Total abundance and biomass of prey within a transect were estimated using the area cover $\left(\mathrm{m}^{2}\right)$ by different algae morphotypes multiplied by the abundances and biomass of prey items found (per $\mathrm{m}^{2}$ ) within respective algae cuttings (see above). Organisms were only considered prey if they were of the relevant taxa and sizes as identified by the stomach content analysis described above.

\section{Sampling of juvenile fish}

Using hand-held nets, a sample of approximately 30 juvenile fish of each of the study species were collected from each of the 32 sampling stations (see Dataset S5 for fish size data). In addition to the stomach content analysis, the fish sample was used to evaluate the size distribution of juvenile fish.

\section{Wave exposure data}

As juvenile fish may experience higher dispersal from habitats with high wave action, and algae may be influenced by physical wave stress, wave exposure was considered in the study (Spatharis et al., 2011). Wave stress data for each station was calculated from a dynamical coastal wave model provided by the Coastal Ocean Observing and Forecasting System located in the Balearic Islands (SOCIB) using past real weather events. The mean wave exposure, as well as the wave exposure of the 4 months prior to sampling, was used as an environmental parameter in the analysis of data.

\section{Statistical analysis} Algae community analysis over temporal and spatial scales

Algae morphotype cover composition was analyzed using a Principal Component Analysis (PCA) based on Euclidian distance. The resulting ordination was explored through investigating the correlation of algae morphotypes with the two first Principle Component (PC) axes. Furthermore, the loading of each variable was superimposed as arrows over 
the ordination. The length of the arrow corresponds to the strength of influence on the ordination, while its orientation provides information on the direction of influence. ANOSIM pairwise comparisons were used to test for significant differences in algae cover composition between the transects sampled between different seasons and islands. Distance based linear models (DistLM) were used to investigate the environmental variables that best explained the observed ordination patterns in algae composition. The following five environmental variables were used: mean depth, slope, rugosity, temperature, wave stress and herbivore density (Salpa salpa and sea urchins), and. All multivariate analyses were conducted with the Software Package Primer-E version 6 (Clarke \& Gorley, 2006).

The height of different algae morphotypes was compared on an island scale using a two-way ANOVA with morphotype and season as main factors. A Post-hoc Tukey-test was used to identify height differences between morphotypes within seasons and the height of the same morphotype between seasons. Height data was log-transformed prior to analysis to meet model assumptions regarding normality and homogeneity of variance.

\section{Potential prey availability in different algae morphotypes for juvenile fish}

Potential prey availability was calculated considering prey sizes, taxonomic groups and the season relevant to the juveniles of the respective fish species $(<60 \mathrm{~mm})$. Potential prey availability was compared between morphotypes using a one-way ANOVA and post-hoc Tukey pairwise comparison tests. The data of both islands were pooled to compare all algae morphotypes since for some algae morphotypes insufficient specimens were sampled to be able to consider both islands separately in the analysis. Potential prey density was log-transformed prior to analysis to meet model assumptions regarding normality and homogeneity of variance.

\section{Relationship between different algae morphotypes and juvenile fish abundances}

The relationship between juvenile fish abundance and algae morphotype cover $\left(\mathrm{m}^{2}\right)$, as well as total prey biomass per transect, was modeled using a Generalized Linear Mixed Model (GLMM) with a negative binomial error distribution and a log-link function. Within the model the station was considered a random factor, to address the dependency structure of dive transect from the same station. The cover by morphotypes, as well as total prey biomass per transect, were considered as fixed factors. All variables introduced to the model were correlated prior to analysis to identify any collinear variables to be removed or pooled prior to modelling. Model selection procedures were adopted whereby non-significant variables were removed until only significant variables were contained in the final model, using the drop-one procedures in R. Models were checked for over dispersion and the residuals were visually examined (Zuur et al., 2009; Zuur, Ieno \& Elphick, 2010). 


\section{RESULTS}

\section{Algae morphotype composition and height across sampling seasons and islands}

Algae morphotype composition within sampling areas and season were compared by PCA ordination of the dive transects sampled. The PCA explained $60.5 \%$ of the variability of the algae cover data (Fig. 3, Table S1). The ANOSIM pairwise comparisons analysis verified that there were significant differences in composition of morphotypes between all island and season combinations ( $p<0.001$, Fig. 3 ). The largest differences were found between transects surveyed in summer in Menorca and all other island-season combinations (see Fig. 3 and Table S1). Algae cover was most similar between spring and summer in Mallorca (see Fig. 3). Transects sampled in spring in Menorca were similar to those sampled in Mallorca (see overlap of PCA space Fig. 3 and lower summed Euclidian squared distance Table S2). Overall, seasonal changes in algae cover for both islands were similar for most morphotypes (Table 1). In both islands, the average transects cover of 1-ET (Cystoseira spp.) were lower in summer compared to spring as was the cover of 2-SL and 3-FI (Dictyota spp. and similar). In contrast, the cover of 7-LB (P. pavonica) was higher in both islands during summer as did the occurrence of barren patches (no vegetation over rock) (Table 1). However, the magnitude of seasonal change was more pronounced in Menorca. Furthermore, transects surveyed in summer were significantly different to those sampled in Mallorca (Fig. 3 and Table S2) with higher cover in morphotype 7-LB (P. pavonica) and lower turf forming morphotypes 8-TF (Corallinaceae) compared to Mallorca (Fig. 3 and Table 1). Morphotypes 2-SL and 3-FI (Dictyota spp. and similar) formed part of many transects in Mallorca in late summer, while these morphotypes were almost absent from transects in Menorca (Fig. 1 and Table 1).

The distance-based linear model (DistLM) relating environmental variables to the PCA ordination of algae cover showed that of the 6 environmental variables considered, three (Temperature, wave stress and rugosity) proved to show significant relationships with the PCA ordination pattern (Fig. 3 and Table S3). The model with the best fit (lowest AIC) containing these three variables had an $\mathrm{r}^{2}$ of 0.2 thus explaining about $20 \%$ of the variability. Mean depth, slope and herbivore density (Salpa salpa and urchins) were not significantly correlated with the ordination (Table S3). Temperature and wave stress were associated with PC1 as indicated by the horizontal orientation of the eigenvectors in Fig. 3 and thus could be related to the distinct algae cover in Menorca over the summer period. In general, average wave stress was higher $\left(\mathrm{H}_{\mathrm{s}} 0.7\right)$ and temperature lower $\left(25.8^{\circ} \mathrm{C}\right)$ in Menorca compared to Mallorca during summer surveys $\left(\mathrm{H}_{\mathrm{s}} 0.4\right.$ and $26.9^{\circ} \mathrm{C}$ respectively).

Additional to the surface cover, the height of algae varied between morphotypes, seasons and islands (Fig. 4). The height of morphotypes was higher in Mallorca compared to Menorca. Seasonal changes in the height of cover were, however, relatively consistent over both areas. Overall, Cystoseira spp. (1-ET) decreased in height between spring and summer surveys (Fig. 4). In Mallorca Cystoseira spp. decreased in height from spring to late summer from an average $11.2 \mathrm{~cm}$ to $4.3 \mathrm{~cm}$, while in Menorca it decreased from $7.6 \mathrm{~cm}$ to $5.1 \mathrm{~cm}$. These reported changes were statistically significant (Tables S4 and S5). Other morphotypes 

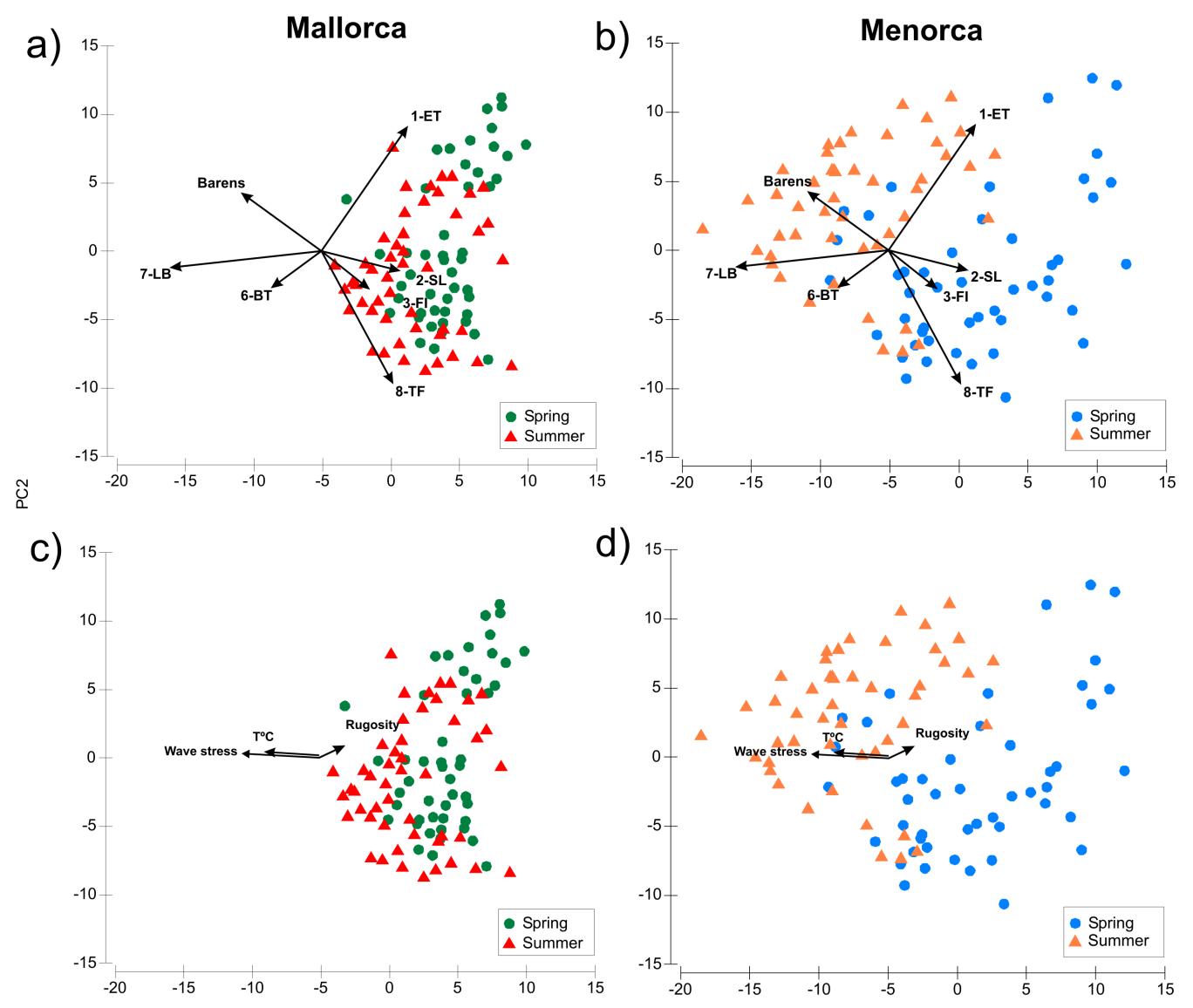

PC1

Figure 3 Comparison of algae morphotype composition in dive transects sampled during spring and summer in Mallorca and Menorca. PCA showing the composition of algae morphotype cover over dive transects surveyed in summer and spring (A: Mallorca, B: Menorca), as well as the potential environmental drivers in the variation of algae morphotype cover. (C: Mallorca, D: Menorca).

Full-size DOI: 10.7717/peerj.6797/fig-3

decreased less in height (2-SL) or approximately maintained their height (3-FI, 6-BT and 8 -TF). In summer, $P$. pavonica (7-LB) was the only algae that significantly increased in height in both areas from 4.2 to $6.9 \mathrm{~cm}$ in Mallorca and 3.8 to 6.8 in Menorca. During the summer period in Mallorca filamentous morphotype algae (3-FI) were found to be the highest with $10.6 \mathrm{~cm}$, while in Menorca both filamentous (3-FI) and bulbus tree-like (6-BT) were the highest with 7.8 and $7.9 \mathrm{~cm}$ respectively.

\section{Taxonomic composition and size of prey items found in juvenile fish stomachs}

Stomach samples of the three-study species showed that all three species shared many prey taxa (see Fig. 5). D. vulgaris and S. occelatus diets were dominated harpacticoids (both $53 \%$ ) while stomachs of $C$. julis predominantly by gastropods (50\%) and to a lesser extent Harpacticoids (34\%). D. vulgaris stomach samples were furthermore dominated by 
Table 1 Morphotype cover during spring and summer in Mallorca and Menorca. Percentage occurence of algae in dive transects and mean algae morphotype cover $\left(\mathrm{m}^{2}\right)$ in Mallorca and Menorca during spring and summer sampling. Arrows indicate average increases or decreases in algae cover between sampling seasons at respective Islands.

Mallorca

Menorca

\begin{tabular}{|c|c|c|c|c|c|c|c|c|c|c|c|c|c|c|}
\hline \multirow{2}{*}{$\begin{array}{l}\text { Season } \\
\text { Morphotypes }\end{array}$} & \multicolumn{3}{|c|}{ Spring } & & \multicolumn{3}{|c|}{ Summer } & \multicolumn{3}{|c|}{ Spring } & & \multicolumn{3}{|c|}{ Summer } \\
\hline & $\%$ occ. T. & Mean & S.D. & & $\%$ occ. T. & Mean & S.D. & $\%$ occ. T. & Mean & S.D. & & $\%$ occ. T. & Mean & S.D. \\
\hline 1-ET & 89.6 & 5.8 & 5.1 & $>$ & 79.2 & 3.0 & 3.7 & 64.6 & 5.6 & 6.0 & $>$ & 60.4 & 4.0 & 4.1 \\
\hline 2-SL & 100.0 & 4.1 & 2.6 & $>$ & 18.8 & 2.6 & 2.6 & 2.1 & 0.2 & 0.8 & $>$ & 87.5 & 0.1 & 0.8 \\
\hline $3-\mathrm{FI}$ & 95.8 & 3.5 & 2.1 & $>$ & 83.3 & 1.9 & 2.9 & 35.4 & 3.5 & 3.3 & $>$ & 56.3 & 0.6 & 1.1 \\
\hline 4-TU & 56.3 & 1.5 & 2.8 & $>$ & 12.5 & 0.4 & 1.4 & 6.3 & 0.0 & 0.1 & $>$ & 16.7 & 0.1 & 0.6 \\
\hline 5-PL & 45.8 & 0.5 & 1.0 & $>$ & 14.6 & 0.0 & 0.0 & 0.0 & 0.1 & 0.2 & $>$ & 0.0 & 0.0 & 0.0 \\
\hline 6-BT & 85.4 & 1.7 & 1.6 & $>$ & 66.7 & 0.4 & 1.2 & 64.6 & 1.9 & 2.6 & $<$ & 27.1 & 2.4 & 3.3 \\
\hline 7-LB & 95.8 & 2.7 & 1.8 & $<$ & 97.9 & 4.0 & 2.7 & 100.0 & 6.8 & 4.0 & $<$ & 91.7 & 12.2 & 5.1 \\
\hline $8-\mathrm{TF}$ & 100.0 & 6.8 & 3.5 & $>$ & 100.0 & 9.4 & 4.0 & 72.9 & 9.9 & 4.5 & $>$ & 100.0 & 3.2 & 3.8 \\
\hline Barens & 37.5 & 0.5 & 1.0 & $<$ & 33.3 & 5.6 & 3.5 & 97.9 & 0.7 & 2.2 & $<$ & 91.7 & 5.8 & 3.7 \\
\hline
\end{tabular}

a)

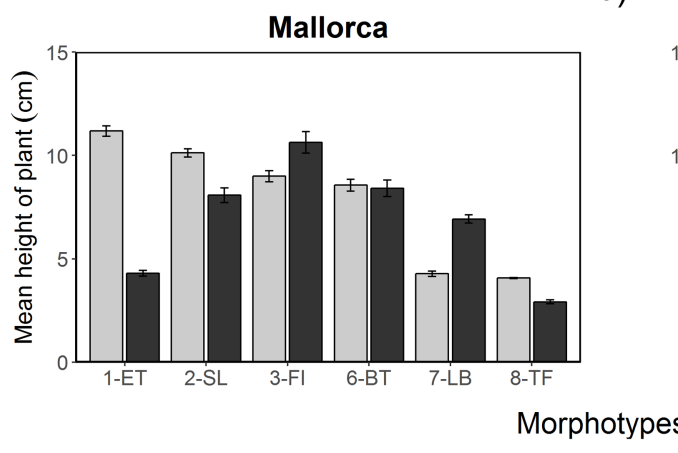

b)

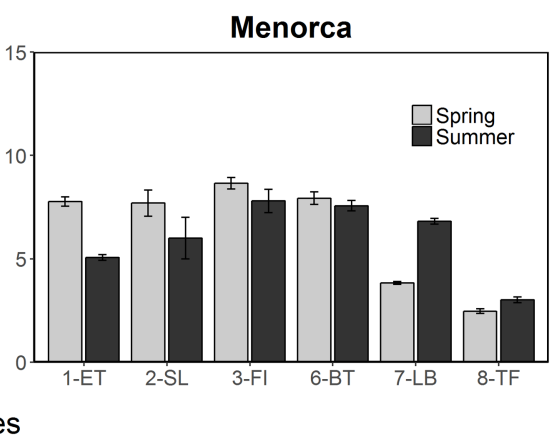

Figure 4 Height of algae morphotypes during spring and summer in Mallorca and Menorca. Mean height of algae morphotypes during spring (May 2014) and summer (August 2014) in (A) Mallorca and (B) Menorca measured within $0.5 \mathrm{~m}^{2}$ quadrats. Error bars are S.E.

Full-size DOI: 10.7717/peerj.6797/fig-4

Ostracods (14\%), Amphipods (9\%) and Gastropods (9\%), while S. occelatus also contained sea mites (Acari 34\%) and Gastropods (15\%).

For all species, significant upper quantiles $(p<0.05)$ were found determining the upper limit of prey sizes that were consumed at a certain size (Fig. 5). Comparing the upper limit of prey sizes consumed with increasing size of fish showed that fish below $60 \mathrm{~mm}$, of the three-study species consumed very similar size prey when considering compact body prey such as Harpacticoids or Amphipods. In general prey sizes were between 1.33-1.61 mm. Both D. vulgaris and C. julis consumed elongated prey consisting mainly of Polychaetes reflected in the $\%$ contribution to the diet, $3 \%$ and $6 \%$ respectively (Fig. 5). Other elongated taxa such, Diptera larvae, Caprellidea and Tanaidacea contributed less to this prey category. Stomachs of $S$. occelatus had too few elongated prey items to perform an upper quantile regression analysis. The size of elongated prey found in C. julis were slightly larger for fish at a size of $60 \mathrm{~mm}$ compared to D. vulgaris. The size elongated taxa consumed was below 
a)

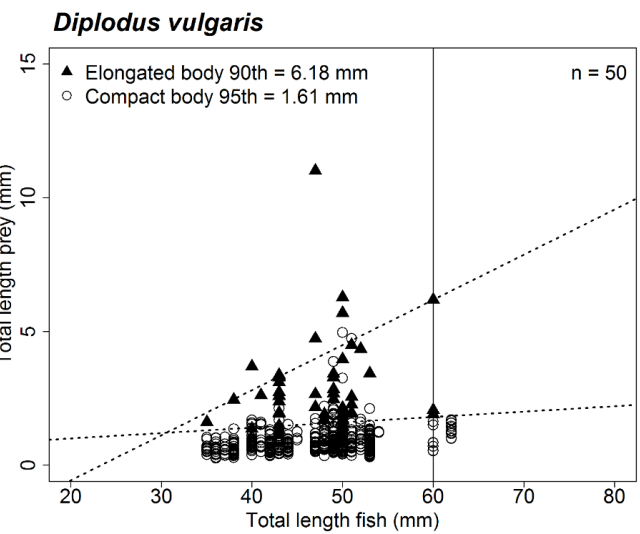

C)

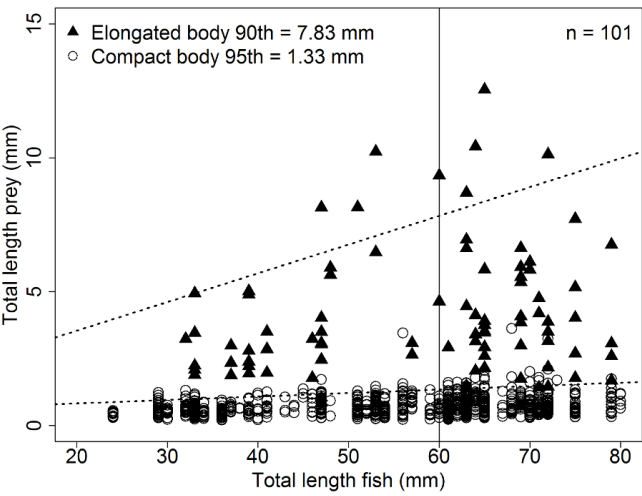

e)

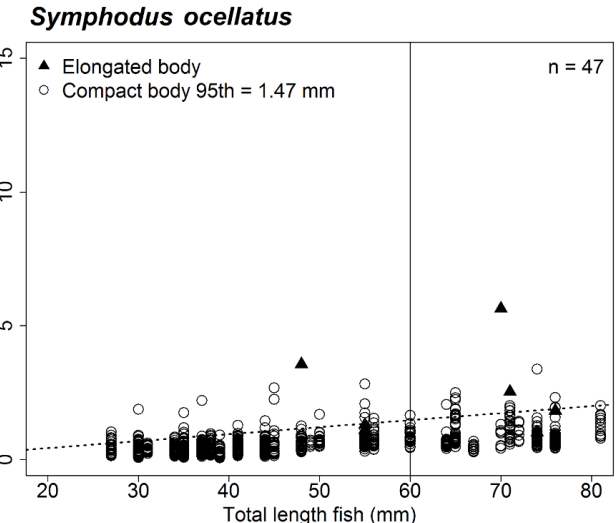

b)

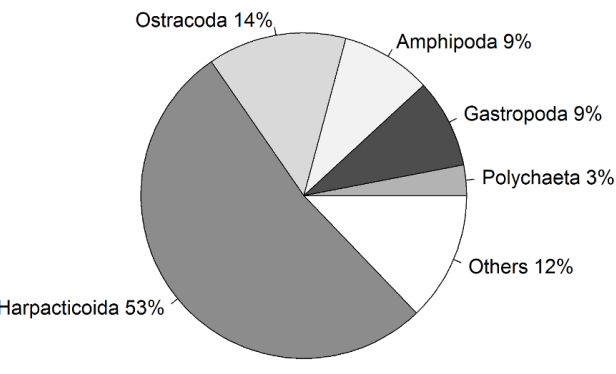

d)

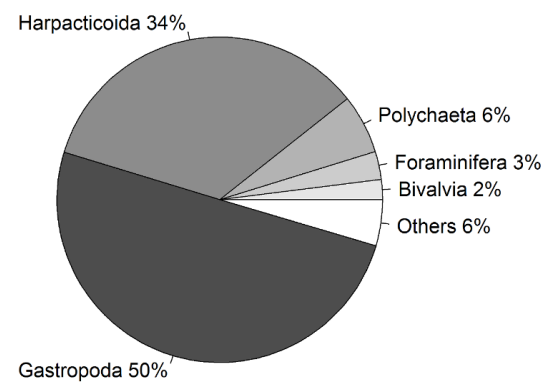

f)

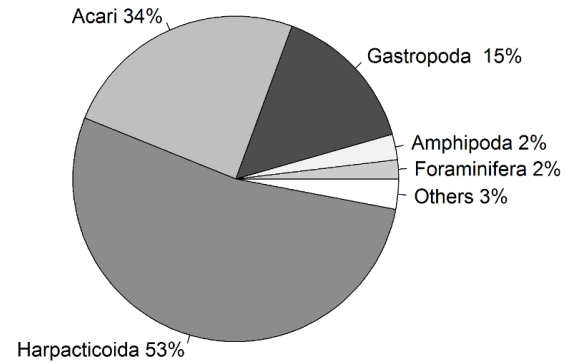

Figure 5 Relationship of fish size and prey size as well as overall taxonomic composition of prey ingested. Graph (A, C and E) showing size distribution of ingested pey for different sized predators. The upper prey size limit for fish of up to $60 \mathrm{~mm}$ was determined by quantile regression for both elongated body prey (i.e., Polychaetes, Diptera larvae, Caprellidea and Tanaidacea) and compact body prey. Only significant upper quantiles were considered starting from the 95th quantile moving down in steps of 5 points. The first significant upper quantile was considered the upper limit. Due to the rare occurrence of elongated prey in Symphodus ocellatus stomachs no specific upper boundary could be established for elongated prey for this species. Size limits of prey for fish below $60 \mathrm{~mm}$ total length for both prey body shapes are given in the graphs (intersect of upper quantile regression with $60 \mathrm{~mm}$ vertical line), as well as the number of fish analyzed $(n)$. Pie charts (B, D and F) showing the proportional contribution of taxa found in fish stomachs analyzed. The five most dominant taxa are shown, all other taxa were pooled under the category others. 
a)

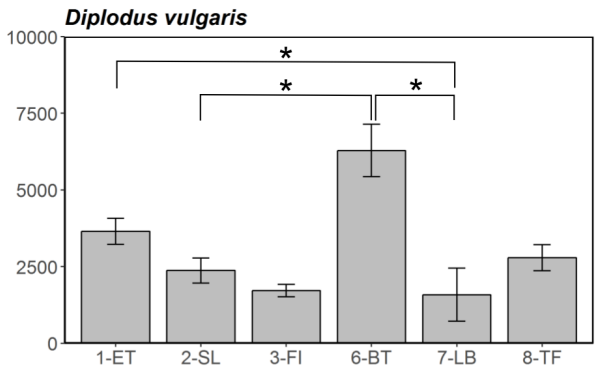

c)

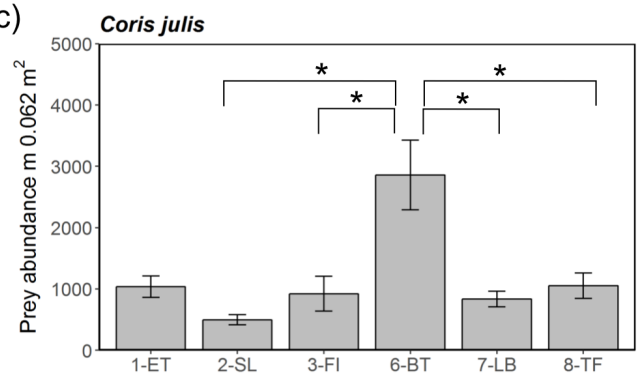

e)

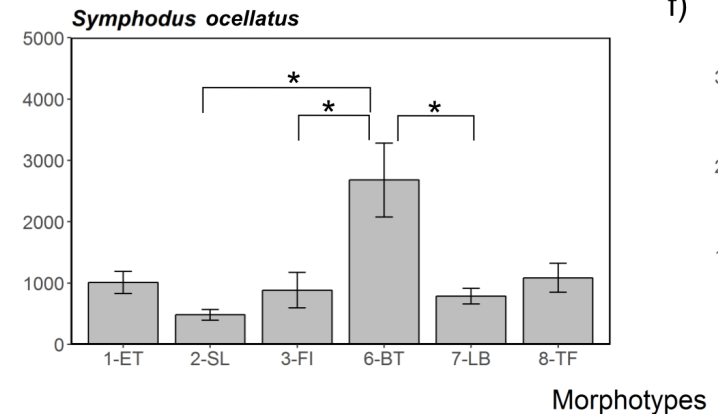

b)

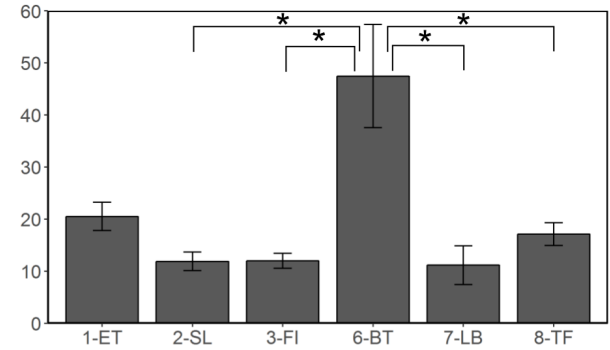

d)

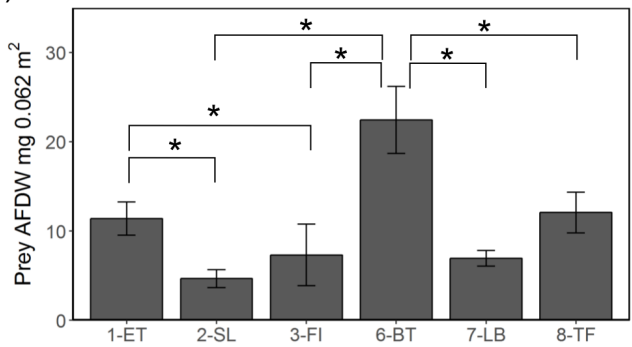

f)

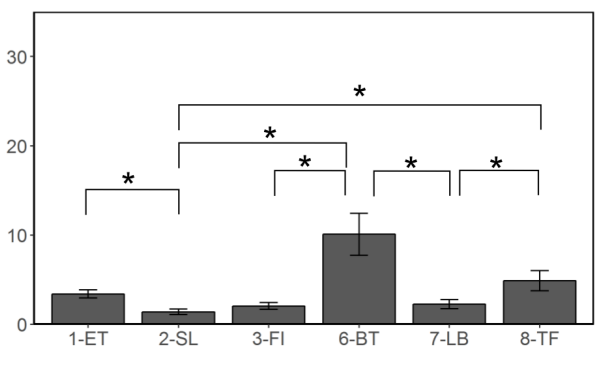

Figure 6 Prey availability in different algae morphotypes. Prey availability with respect to abundance (A, C, E) and biomass as AFDW (B, D, F) per $0.067 \mathrm{~m}^{2}$ within different algae morphotypes. Significant $(p<0.05)$ pairwise comparisons of from the post-hoc analysis are marked with a bracket and an asterisk. Full-size $₫$ DOI: 10.7717/peerj.6797/fig-6

$6.18 \mathrm{~mm}$ and $7.83 \mathrm{~mm}$ respectively (see Fig. 5). Overall the stomach content reflected well the dominant taxa found in the different algae morphotypes (Table S6).

\section{Potential prey availability in different algae morphotypes for juvenile fish}

Comparing potential prey abundance and biomass by algae morphotype using one-way ANOVA analysis showed that there were significant differences considering the three-study species (Table S7 and Fig. 6). Post-hoc Tukey tests showed that in general 1-ET and 6-BT held significantly higher prey densities and biomass compared to other algae morphotypes (S15 and Fig. 6). Overall, the highest prey densities or biomasses in absolute terms were, irrespective of season and fish species, found in the three structurally complex algae 1-ET, 6-BT and 8-TF, compared to the more structurally simple algae, such as 2-SL, 3-FI and 7-LB. The general pattern between islands and seasons observed in prey abundances and 
Table 2 Number and sizes of juvenile fish observed during spring and summer in Mallorca and Menorca. Summary table of the total number of fish observed in visual censuses and their sizes in $\mathrm{mm}$, measured from a capture subsample (see 'Method' section). The table also includes the number of other Sympodus species encountered and the number of adults observed over transects by sampling season and island.

\begin{tabular}{|c|c|c|c|c|c|}
\hline & & \multicolumn{2}{|c|}{ Spring } & \multicolumn{2}{|c|}{ Summer } \\
\hline & & Mallorca & Menorca & Mallorca & Menorca \\
\hline \multirow[t]{3}{*}{ D. vulagris } & No. of juveniles & 35 & 4 & - & - \\
\hline & Size of juveniles in mm (caught) & $43.8(3.8) n=105$ & $46.1(5.7) n=46$ & & \\
\hline & No. of adults & 188 & 168 & 508 & 229 \\
\hline \multirow[t]{3}{*}{ C. julis } & No. of juveniles & - & - & 181 & 245 \\
\hline & Size of juveniles in mm (caught) & & & $48.7(5.2) n=19$ & $32.7(10.3) n=168$ \\
\hline & No. of adults & 314 & 373 & 743 & 528 \\
\hline \multirow[t]{4}{*}{ S. ocellatus } & No. of juveniles & - & - & 486 & 63 \\
\hline & Size of juveniles in mm (caught) & & & $28.1(14.6) n=371$ & $33.3(9.7) n=51$ \\
\hline & No. of adults & 220 & 90 & 186 & 34 \\
\hline & No juveniles other $S . \operatorname{spp}$. & & & 48 & 20 \\
\hline
\end{tabular}

biomass were reflective of patterns when considering all associated fauna (Fig. S1). Note that overall abundances and biomass of associated fauna were considerably higher within all algae morphotypes in spring compared to summer (Fig. S1).

\section{Relationship between different algae morphotypes and juvenile fish abundances}

The total number of juvenile fish observed over the visual transects surveyed varied considerably between islands and species. For D. vulgaris we only encountered 39 fish in 96 transects during the spring period of which 35 were recorded in Mallorca (mean size $43.8 \mathrm{~mm}$ Mallorca and $46.1 \mathrm{~mm}$ Menorca). In contrast, similar numbers of $C$. julis were recorded at both islands during the summer sampling period see Table 2 (mean size 48.7 $\mathrm{mm}$ Mallorca and $32.7 \mathrm{~mm}$ Menorca). However, for S. ocellatus the number of juveniles varied considerably between islands. In 48 transects we observed 486 fish in Mallorca as opposed to only 63 in Mallorca (mean size $28.1 \mathrm{~mm}$ Mallorca and $33.3 \mathrm{~mm}$ in Menorca). This island scale difference was also reflected in other Symphodus species (see Table 2).

Due to the low abundance of $D$. vulgaris juveniles in visual census transects we did not investigate their relationship with algae cover and total prey biomass within transects using a Generalized Linear Mixed Modelling (GLMM) approach. Furthermore, we restricted this type of analysis to Mallorca for $S$. ocellatus where we had a sufficiently large sample size. $C$. julis was analyzed considering data from both islands.

Prior to the GLMM analysis we correlated the explanatory variables to detect any collinearity. As we found a positive correlation between 2-SL and 3-FI (Pearson correlation coefficient 0.68 ) and as the two algae morphotypes were structurally and taxonomically similar, their cover was pooled to avoid collinearity.

For C. julis neither algae cover, nor the total prey biomass had a significant effect on juvenile abundances. For $S$. ocellatus the best model including only the significant variables contained the algae morphotypes 2-SL+3-FI and 7-LB. While 2-SL+3-FI had a positive effect on fish abundances 7-LB had a negative effect (Table 3 and Fig. 7). 
Table 3 Relationship of $S$. occelatus juvenile density with algae morphotypes. Summary table of the total number of fish observed in visual censuses and their sizes in mm measured from a capture subsample (see 'Method' section). The table also includes the number of other Sympodus species encountered and the number of adults observed over transects by sampling season and island.

\begin{tabular}{lllllll}
$\begin{array}{l}\text { GLMM } \\
\text { Species }\end{array}$ & Conditional model: & Estimate & Std.Error & $\boldsymbol{z}$-value & $\boldsymbol{p}$-value & \\
\hline S. ocellatus & (Intercept) & 2.10 & 0.28 & 7.37 & 0.0000 & $* * *$ \\
& 2-SL + 3-FI & 0.12 & 0.03 & 3.72 & 0.0002 & $* * *$ \\
& 7-LB & -0.15 & 0.06 & -2.38 & 0.0172 & $*$ \\
\hline
\end{tabular}

\section{a) S. ocellatus}

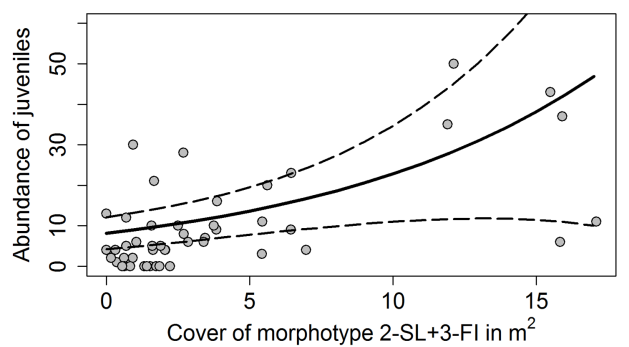

b)

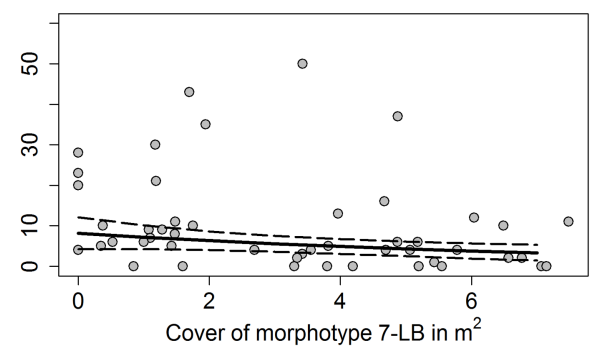

Figure 7 Density of $S$. ocellatus with different algae morphotype cover. Results of the generalized mixed variable intercept model (A) morphotypes 2-SL+3-FI (Dictyotales) and (B) morphotype 7-LB ( $P$. pavonica). Solid line represents predicted juvenile abundances of the GLMM model and dashed lines the 95\% C. I. Data points represent individual transects. Detailed summary of results presented in Table 3.

Full-size DOI: 10.7717 /peerj.6797/fig-7

\section{DISCUSSION}

High quality habitats for juvenile coastal fish have generally been characterized by both, high sheltering opportunities and food for the resident juvenile fish (Cheminée et al., 2013; Cheminée et al., 2017). In our study, we however observed that the occurrence of juvenile fish in late summer appeared to coincided with a period of less optimal habitat conditions. Our results showed strong seasonal variations in algae cover between sampling seasons. Algae morphotype cover and height had changed considerably on both islands between the two sampling events that coincided with the two major settlement peaks of juvenile fish documented for the Mediterranean (Garcia-Rubies \& Macpherson, 1995; Biagi, Gambaccini \& Zazzetta, 1998; Bussotti \& Guidetti, 2011). During the settlement period of D. vulgaris the extent and height of the forest forming algae Cystoseira spp. was considerably greater compared to the summer period in which S. ocellatus and C. julis settled. Similarly, most other algae decreased in cover and to some extend in height except for P. pavonica, which increased both in cover and height during this period. Concurrent with these cessation patterns of algae, the associated fauna was also found to undergo a sharp seasonal decline in abundance and biomass, from spring to summer. However, this was not restricted to algae that decreased in height but was a consistent pattern which was also found to affect algae that increased in height, such as $P$. pavonica. Thus, when comparing overall prey availability per unit area between fish species, there were considerably more prey available 
in algae during the spring period at D. vulgaris settlement, compared to prey available for the other species during the late summer period. These seasonal patterns between algae and associated fauna have also been demonstrated by other authors (e.g., Guerra-García et al., 2011). An apparent mismatch exists between the period of high shelter and food provision by habitats and the settlement and growth period of juvenile fish. Summer settlement of juveniles results from spawning during early spring and the mismatch may be caused by evolutionary processes favoring the match of earlier larvae stages with planktonic production processes, ensuring higher larval survival. Certainly, for C. julis there appear to be strong links between primary production processes and the amount of larval settlement (Fontes et al., 2016), which may also apply to other fish species with summer settlement peaks in the Mediterranean. This mismatch, therefore, does not suggest that shelter and food are not important for juveniles, but that they do not appear to have a strong selective influence on the timing of spawning. The decrease of shelter and food provisioning from spring to summer shows that coastal habitats and the services they provide for juveniles are not a constant and that they can undergo notable changes in a relatively short amount of time. With this in mid, it is plausible that climate change may further increase the mismatch between algae habitat provisioning properties and summer settlers, if higher temperatures increase the speed of seasonal cycles causing earlier cessation in algae communities. Little is currently known about the influence of climate change on the timing of seasonality in macroalgae. Several studies argue that warming can affect the phenology and reproduction of macroalgae (Kraufvelin et al., 2012; Andrews, Bennett \& Wernberg, 2014), thus suggesting that early cessation processes could be triggered by seasonally early or extreme warming events. For example, in the Baltic, increased seawater temperature and light during early springs accelerate receptacle growth of Fucus vesiculosus, causing earlier reproduction (Kraufvelin et al., 2012). As cessation processes generally follow reproduction in many marco-algae species (Liu et al., 2017), climate change has the potential to shorten macroalgae cycles potentially causing a mismatch between the provision of shelter and food for juvenile fish (Durant et al., 2007). Both the timing of spawning and the rate of larvae and juvenile development may, however, also be affected by temperature (Pankhurst $\&$ Munday, 2011). Therefore, it is also conceivable that both juvenile fish and habitat may be affected synchronously. The precise effect of temperature on reproduction and larvae development of fish is, however, complex and highly species-specific. Thus, for example warming may advance or delay the maturation and ovation depending on species specific thermal endocrine triggers (Pankhurst \& Munday, 2011). Climate induced mismatches between fish and their food resources have been reported for pelagic fish, illustrating that climate warming may not affect larval development and prey production equally (Gröger, Hinrichsen \& Polte, 2014; Illing et al., 2018). Whether the match/mismatch hypothesis, i.e., the synchronized/desynchronized timing of seasonal activities, as described by Cushing $(1969,1990)$, is important with respect to algae habitats provisions for juvenile fish is currently unknown and requires further scientific attention.

When considering the potential prey availability in different macroalgae morphotypes, we found that structurally more complex algae contained more prey, in particular, algae such as Halopteris spp. and Cystorceria spp., but also turf forming Corallinaceae such as 
Haliption vigatum, that have a complex internal structure. In contrast, Dictyotales, with flat leafs or filamentous algal species, contained fewer prey. This pattern of distribution of prey amongst algae was persistent during both settlement periods. Whether algae containing higher prey biomasses also provide higher quality habitats is unclear. The term potential prey availability was used throughout as we did not examine whether this prey was readily available to the juvenile fish. It is possible that, due to the complex structure of some algae, feeding efficiency of juveniles may be decreased or less optimal (Tátrai \& Herzig, 1995). Thus, the higher amounts of associated invertebrate fauna in morphologically complex algae could reflect reduced predation by fish. Equally, lower biomass of potential prey within less complex algae morphotypes could be the result of increased feeding on less protected and thus easier to feed upon prey. As a result, it is possible that juveniles are responsible for structuring the associated algal fauna. Further research into juvenile feeding behavior will be required to explain observed prey distributions among algae morphotypes.

Within our study, no tangible indication appeared within the data that juvenile fish densities are strongly linked to prey densities. For example, S. ocellatus, was associated to algae with the least prey. It is likely that food availability is of secondary importance to fish abundance, but it may, nevertheless, affect juvenile body condition and growth rate and thus their long term-survival (Lloret et al., 2002; Lloret et al., 2012). To assess and compare nursery qualities of habitats and move away from using solely abundance estimates for habitat suitability, these parameters should be considered by future studies.

Analyzing the association of juvenile fish abundance and algae morphotype cover, we discovered that, while for $C$. julis there was no clear association to any particular algae morphotype, S. ocellatus had a positive association with Dictyotales and a negative association with P. pavonica. No analyses were carried out for D. vulgaris, as too few individuals were observed within transects. The absence of a clear relationship of $C$. julis with algae morphotype appears consistent with findings by Cheminée et al. (2017), who reported an association of this species with sparser algae cover. However, we found no clear relationship between the abundance of S. ocellatus and Cystoseria contrary to the patterns observed by other studies (e.g., Cheminée et al., 2013; Cheminée et al., 2017; Thiriet et al., 2016). These studies stress the importance of Cystoseira forests as a prime juvenile habitat for Symphodus spp., due to their structure. These discrepancies could be due to different factors such as: (i) the different UVC methodlogy used in the different studies $\left(15^{\star} 2 \mathrm{~m}\right.$ transects this study, $1 \mathrm{~m}^{2}$ point-count (Cheminée et al., 2013; Cheminée et al., 2017) and 9- $\mathrm{m}^{2}$ stationary-point snapshot count (Thiriet et al., 2016)), which can have an effect on the total amount of fish counted; (ii) different geographical and temporal settlement peaks of local populations, which can produce a mismatch between the time of the study and the time of the settlement in each study area and year of sampling (iii) seasonal and annual differences in the development of height and cover of Cystoserira. Within our study Dictyotales provided considerably higher cover, compared to Cystoseira, and may have therefore been more important in providing shelter to Symphodus spp. The low numbers of individuals of this species in Menorca were not only restricted to juveniles but also fewer adults were observed, possibly indicating that habitats surveyed in this island were altogether less suitable for this species. Apart from potentially having provided 
better sheltering opportunities, Dictoytales were observed to be an important nest building material for male S. occelatus, during spring in Mallorca. Many labridae species build nests in which the male protects and broods the fertilized eggs (Raventós, 2006). Thus, it is possible that the higher abundances of juveniles observed in Dictoytales dominated habitats may be related to a higher number or quality of nests, subsequently providing a locally larger numbers of settlers in summer. However, a study on the related species Symphodus roissali found no significant relationship between the indirect measure of successful nests (larval output) and the number of recruits within a three year period (Raventos, 2009). It remains unclear if the shelter, or better nesting conditions, were responsible for higher abundances of S. ocellatus in Dictoytales in our study.

Overall, more effort needs to be made to study the behavioral relationship and interaction of fish with their habitats. This and other studies focused on measuring the percentage cover of algae for shelter and food provisioning. Shelter, however, may be used in different configurations. For example, fish may use banks/patches of algae to hide from predators behind or hide within the algae matrix. Hiding behind would require high cover but in a fragmented format, with open spaces, whereas hiding within would require a more continuous cover. In our study, while catching juvenile fish, we observed that $S$. ocellatus hid within the algae matrix, while D. vulgaris avoided entering any algae or Posidonia patches but instead used these as a parkour of obstacles to outpace and loose human pursuers. In the case of D. vulgaris, a continuous dense algae forest cover, may due to this behavior, not represent an ideal habitat. This type of behavioral shelter use may explain why no trends were observed for this species and shows that future studies also needs to consider the spatial configuration of cover depending on the behavioral needs of a species.

\section{Conclusion and recommendations for future studies}

The results of this study show that in many ways we still have a relatively rudimentary understanding of what represents a good nursery habitat for juvenile fish. Algae species such as Cystoseira that appear to have high importance in one area and season for a specific species may not necessarily have the same importance in another area or season. This may be due to the context dependent nature of juvenile occurrence and the habitat composition at the time of the study. The results suggest that fish can adapt to local situations and use algae morphotypes/species that offer the required function at the time. While at the time of our study we detected an association of $S$. ocellatus juveniles $(3-4 \mathrm{~cm})$ with Dictoytales these results do not implicate that Cystoseira habitats are not important for juvenile fish. Settlers that arrived in July-early August may well have used Cystoseira to shelter within the first two months of their lives. Equally likely, those new settlers of other species arriving in the area during the spring, when the Cystoseira forest are better developed with higher cover and canopy height may have a preference for this algae over others. While providing new insights, the present study is not able to evaluate the importance of Cystoseira habitats as a nursery habitat with certainty and as such the effect of the continuing loss of this habitat. Considerably more focused research will be required to address this question.

Abundance of juvenile fish may vary considerably in time, at any one location, due to natural stochastic processes, causing a high degree of variability. Scenarios are imaginable 
in which, due to a strong settlement pulse and fishery-depleted predators, there are many juveniles in a habitat. However, because of the lack of food provided by the habitat, fish may have low long-term survival potential (e.g., Macpherson et al., 1997; Planes et al., 1999; Cuadros et al., 2018). Using abundance indices alone as a tool to assess habitat quality has limitations, as these do not consider the effect of different habitat conditions on the individual fish, i.e., how a habitat affects parameters such e.g., growth and survival potential. Thus, when combined with abundance estimates, methodologies that assess fish condition, growth performance and health status may provide a more accurate picture of the prevailing conditions for fish living at a certain location. Habitat quality for juveniles should not be measured on the level of "settlement success" alone i.e., the maximum number of recently settled individuals, which may be largely a function of stochastic hydrodynamic processes (Beck et al., 2001). A better measure of habitat quality would be to estimate the survival rate of newly settled fish to reach a certain arbitrary size in good condition. However, measuring this type of "recruitment success" would be time consuming and financially costly as it would require intensive temporal sampling of juveniles from their settlement phase to their recruitment to the adult population. To increase our understanding of what constitutes high quality nursery habitats, it is important to have viable and cost-effective sampling solutions. Therefore, future studies should aim to incorporate methods and develop indicators that link both abundance estimates and population fitness parameters of juvenile fish at an agreed, predefined size range (by species)to evaluate habitat quality.

\section{ACKNOWLEDGEMENTS}

This study was logistically supported by the the Laboratorio de Investigaciones Marinas $y$ Acuicultura (LIMIA) and we would like to thank Elena Pastor and Amalia Grau for their help and commitment. We would like to thank the Balearic Islands Coastal Ocean Observing and Forecasting System (SOCIB) for the provisioning of wave stress data from their forecasting models. Here particular thanks to Amaya Álvarez. We also would like to thank Grace Niamh Tomlinson and Ada Barbanera for assisting in the laboratory work. We also would like to thank Emil Ólafsson for earlier reflections on the study.

\section{ADDITIONAL INFORMATION AND DECLARATIONS}

\section{Funding}

This research received funding through the FP7-People IEF-Marie-Curie Action project LINKFISH (299552) "Investigating the link between sub-littoral algae habitats and fish communities in the Mediterranean Sea". During part of the write-up of this work, Hilmar Hinz was supported by the Ramón y Cajal Fellowship (grant by the Ministerio de Economía y Competitividad de España and the Conselleria d'Educacio, Cultura i Universitats Comunidad Autońoma de las Islas Baleares) and Andrew F. Johnson was supported by NSF grant DEB-1632648 (2016-18). The funders had no role in study design, data collection and analysis, decision to publish, or preparation of the manuscript. 


\section{Grant Disclosures}

The following grant information was disclosed by the authors:

FP7-People IEF-Marie-Curie Action project LINKFISH: 299552.

Ramón y Cajal Fellowship.

Ministerio de Economía y Competitividad de España and the Conselleria d'Educacio.

Cultura i Universitats Comunidad Autońoma de las Islas Baleares.

NSF: DEB-1632648 (2016-18).

\section{Competing Interests}

The authors declare there are no competing interests. Andrew F. Johnson is an employee of MarFishEco.

\section{Author Contributions}

- Hilmar Hinz conceived and designed the experiments, performed the experiments, analyzed the data, contributed reagents/materials/analysis tools, prepared figures and/or tables, authored or reviewed drafts of the paper, approved the final draft.

- Olga Reñones conceived and designed the experiments, performed the experiments, analyzed the data, authored or reviewed drafts of the paper, approved the final draft.

- Adam Gouraguine performed the experiments, analyzed the data, authored or reviewed drafts of the paper, approved the final draft.

- Andrew F. Johnson performed the experiments, authored or reviewed drafts of the paper, approved the final draft.

- Joan Moranta conceived and designed the experiments, performed the experiments, analyzed the data, contributed reagents/materials/analysis tools, authored or reviewed drafts of the paper, approved the final draft.

\section{Data Availability}

The following information was supplied regarding data availability:

All raw data is available in Supplemental Files.

\section{Supplemental Information}

Supplemental information for this article can be found online at http://dx.doi.org/10.7717/ peerj.6797\#supplemental-information.

\section{REFERENCES}

Altin A, Özen Ö, Ayyildiz H, Ayaz A. 2015. Feeding habits and diet overlap of juveniles of 2 sparids, Diplodus puntazzo(Walbaum, 1792) and Diplodus vulgaris (Geoffroy Saint-Hilaire, 1817), from theNorth Aegean Sea of Turkey. Turkish Journal of Zoology 39:80-87 DOI 10.3906/zoo-1312-2.

Andrews S, Bennett S, Wernberg T. 2014. Reproductive seasonality and early life temperature sensitivity reflect vulnerability of a seaweed undergoing range reduction. Marine Ecology Progress Series 495:119-129 DOI 10.3354/meps10567. 
Beck MW, Heck KL, Able KW, Childers DL, Eggleston DB, Gillanders BM, Halpern B, Hays CG, Hoshino K, Minello TJ, Orth RJ, Sheridan PF, Weinstein MP. 2001. The identification, conservation, and management of estuarine and marine nurseries for fish and invertebrates. BioScience 51(8):633-641 DOI 10.1641/0006-3568(2001)051[0633:TICAMO]2.0.CO;2.

Biagi F, Gambaccini S, Zazzetta M. 1998. Settlement and recruitment in fishes: the role of coastal areas. Italian Journal of Zoology 65(sup1):269-274 DOI 10.1080/11250009809386831.

Bologna PA, Heck KL. 2002. Impact of habitat edges on density and secondary production of seagrass-associated fauna. Estuaries 25(5):1033-1044 DOI 10.1007/BF02691350.

Bussotti S, Guidetti 1. 2011. Timing and habitat preferences for settlement of juvenile fishes in the Marine Protected Area of Torre Guaceto (south-eastern Italy, Adriatic Sea). Italian Journal of Zoology 78(2):243-254 DOI 10.1080/11250001003774652.

Cade B, Noon BR. 2003. A gentle introduction to quantile regression for ecologistsCade-2003-Wiley Online Library. Frontiers in Ecology and the Environment 1(8):412-420 DOI 10.1890/1540-9295(2003)001[0412:AGITQR]2.0.CO;2.

Canion CR, Heck KL. 2009. Effect of habitat complexity on predation success: reevaluating the current paradigm in seagrass beds. Marine Ecology Progress Series 393:37-46 DOI 10.3354/meps08272.

Cheminée A, Merigot B, Vanderklift MA, Francour P. 2016. Does habitat complexity influence fish recruitment? Mediterranean Marine Science 17(1):39-46 DOI 10.12681/mms.1231.

Cheminée A, Pastor J, Bianchimani O, Thiriet P, Sala E, Cottalorda JM, Dominici JM, Lejeune P, Francour P. 2017. Juvenile fish assemblages in temperate rocky reefs are shaped by the presence of macro-Algae canopy and its three-dimensional structure. Scientific Reports 7:14638 DOI 10.1038/s41598-017-15291-y.

Cheminée A, Sala E, Pastor J, Bodilis P, Thiriet P, Mangialajo L, Cottalorda JM, Francour P. 2013. Nursery value of Cystoseira forests for Mediterranean rocky reef fishes. Journal of Experimental Marine Biology and Ecology 442:70-79 DOI 10.1016/j.jembe.2013.02.003.

Clarke KR, Gorley R. 2006. PRIMER v6: User Manual/Tutorial (Plymouth Routines in Multivariate Ecological Research). Plymouth: PRIMER-E.

Cruz-Rivera E, Villareal TA. 2006. Macroalgal palatability and the flux of ciguatera toxins through marine food webs. Harmful Algae 5(5):497-525 DOI 10.1016/j.hal.2005.09.003.

Cuadros A, Basterretxea G, Cardona L, Cheminée A, Hidalgo M, Moranta J. 2018. Settlement and post-settlement survival rates of the white seabream (Diplodus sargus) in the western Mediterranean Sea. PLOS ONE 13(1):e0190278 DOI 10.1371/journal.pone.0190278.

Cushing DH. 1969. The regularity of the spawning season of some fishes. J ICES Journal of Marine Science 33(1):81-92 DOI 10.1093/icesjms/33.1.81. 
Cushing DH. 1990. Plankton production and year-class strength in fish populations: an update of the match/mismatch hypothesis. Advances in Marine Biology DOI 10.1016/S0065-2881(08)60202-3.

Dahlgren CP, Eggleston DB. 2014. Ecological processes underlying ontogenetic habitat shifts in a coral reef fish. Ecology 81(8):2227-2240 DOI 10.2307/177110.

Dayton PK. 1972. Toward an understanding of community resilience and the potential effects of enrichment to the benthos at McMurdo Sound, Antarctica. In: Proceedings of the colloquium on conservation problems in Antarctica. Lawrence: Allen Press, $81-96$.

Doherty PJ, Sale PF. 1986. Predation on juvenile coral reef fishes: an exclusion experiment. Coral Reefs 4(4):225-234 DOI 10.1007/BF00298081.

Duarte CM. 2000. Marine biodiversity and ecosystem services: an elusive link. Journal of Experimental Marine Biology and Ecology 250(1-2):117-131 DOI 10.1016/S0022-0981(00)00194-5.

Duffy JE, Hay ME. 2000. Strong impacts of grazing amphipods on the organization of a benthic community. Ecological Monographs 70(2):237-263 DOI 10.1890/0012-9615(2000)070[0237:SIOGAO]2.0.CO;2.

Durant JM, Hjermann D, Ottersen G, Stenseth NC. 2007. Climate and the match or mismatch between predator requirements and resource availability. Climate Research 33:271-283 DOI 10.3354/cr033271.

Félix-Hackradt FC, Hackradt CW, Treviño Otón J, Pérez-Ruzafa A, GarcíaCharton JA. 2014. Habitat use and ontogenetic shifts of fish life stages at rocky reefs in South-western Mediterranean Sea. Journal of Sea Research 88:67-77 DOI 10.1016/j.seares.2013.12.018.

Fontes J, Semmens B, Caselle JE, Santos RS, Prakya SR. 2016. Ocean productivity may predict recruitment of the rainbow wrasse (Coris julis). PLOS ONE 11(11):e0165648 DOI 10.1371/journal.pone.0165648.

García-Rubies A, Macpherson E. 1995. Substrate use and temporal pattern of recruitment in juvenile fishes of the Mediterranean littoral. Marine Biology 124(1):35-42 DOI 10.1007/BF00349144.

Gee J. 1989. An ecological and economic review of meiofauna as food for fish. Zoological Journal of the Linnean Society 96(3):243-261 DOI 10.1111/j.1096-3642.1989.tb01830.x.

Gröger JP, Hinrichsen HH, Polte P. 2014. Broad-scale climate influences on springspawning herring (Clupea harengus, L.) recruitment in the Western Baltic Sea. PLOS ONE 9:1-14 DOI 10.1371/journal.pone.0087525.

Guerra-García JM, Cabezas MP, Baeza-Rojano E, García-Gómez JC. 2011. Spatial patterns and seasonal fluctuations of intertidal macroalgal assemblages from Tarifa Island, southern Spain: relationship with associated Crustacea. Journal of the Marine Biological Association of the United Kingdom 91(1):107-116 DOI 10.1017/S0025315410001219. 
Guidetti P. 2000. Differences among fish assemblages associated with nearshore Posidonia oceanica seagrass beds, rocky-algal reefs and unvegetated sand habitats in the adriatic sea. Estuarine, Coastal and Shelf Science 50(4):515-529 DOI 10.1006/ecss.1999.0584.

Guidetti P. 2001. Population dynamics and post-settlement mortality of the ornate wrasse, thalassoma pavo, in the tyrrhenian sea (western Mediterranean). Italian Journal of Zoology 68(1):75-78 DOI 10.1080/11250000109356386.

Harmelin-Vivien ML, Harmelin JG, Chauvet C, Duval C, Galzin R, Lejeune P, Barnabe G, Blanc F, Ghevalier R, Duclerc J, Lasserre G. 1985. Evaluation visuelle des peuplements et populations de Poissons méthodes et problèmes. Revue d'Écologie 40:467-539.

Harmelin-Vivien ML, Harmelin JG, Leboulleux V. 1995. Microhabitat requirements for settlement of juvenile sparid fishes on Mediterranean rocky shores. Hydrobiologia 300(1):309-320 DOI 10.1007/BF00024471.

Heck KLJ, Hays G, Orth RJ. 2003. Critical evaluation of the nursery role hypothesis for seagrass meadows. Marine Ecology Progress Series 253:123-136 DOI 10.3354/meps253123.

Illing B, Moyano M, Berg J, Hufnagl M, Peck MA. 2018. Behavioral and physiological responses to prey match-mismatch in larval herring. Estuarine, Coastal and Shelf Science 201:82-94 DOI 10.1016/j.ecss.2016.01.003.

Irving AD, Balata D, Colosio F, Ferrando GA, Airoldi L. 2009. Light, sediment, temperature, and the early life-history of the habitat-forming alga Cystoseira barbata. Marine Biology 156(6):1223-1231 DOI 10.1007/s00227-009-1164-7.

Jackson EL, Jackson EL, Rowden AA, Attrill MJ, Bossey SJ, Jones MB. 2001. The importance of seagrass beds as a habitat for fishery species Oceanography and Marine Biology. Oceanography and Marine Biology 39:269-303.

Jackson EL, Rees SE, Wilding C, Attrill MJ. 2015. Use of a seagrass residency index to apportion commercial fishery landing values and recreation fisheries expenditure to seagrass habitat service. Conservation Biology 29(3):899-909 DOI 10.1111/cobi.12436.

Jaschinski S, Sommer U. 2008. Functional diversity of mesograzers in an eelgrassepiphyte system. Marine Biology 154(3):475-482 DOI 10.1007/s00227-008-0942-y.

Kabasakal H. 2001. Description of the feeding morphology and food habits of four sympatric Labrids (Perciformes, Labridae) from the south-eastern Aegean Sea. Turkey. Netherlands Journal of Zoology 51(4):439-455 DOI 10.1163/156854201X00206.

Kraufvelin P, Ruuskanen AT, Bäck S, Russell G. 2012. Increased seawater temperature and light during early springs accelerate receptacle growth of $\mathrm{Fu}$ cus vesiculosus in the northern Baltic proper. Marine Biology 159:1795-1807 DOI 10.1007/s00227-012-1970-1.

Leslie T, James NC, Potts WM, Rajkaran A. 2017. The relationship between habitat complexity and nursery provision for an estuarine-dependent fish species in a permanently open South African Estuary. Estuarine, Coastal and Shelf Science 198(A):183-192 DOI 10.1016/j.ecss.2017.09.013. 
Lewis LS, Anderson TW. 2012. Top-down control of epifauna by fishes enhances seagrass production. Ecology 93(12):2746-2757 DOI 10.1890/12-0038.1.

Liu X, Bogaert K, Engelen AH, Leliaert F, Roleda MY, De Clerck O. 2017. Seaweed reproductive biology: environmental and genetic controls. Botanica Marina 60:89-108 DOI 10.1515/bot-2016-0091.

Lloret J, Faliex E, Shulman GE, Raga J-A, Sasal P, Muñoz M, Casadevall M, AhuirBaraja AE, Montero FE, Repullés-Albelda A, Cardinale M, Rätz H-J, Vila S, Ferrer D. 2012. Fish health and fisheries, implications for stock assessment and management: the Mediterranean example. Reviews in Fisheries Science 20(3):165-180 DOI 10.1080/10641262.2012.695817.

Lloret J, Gil de Sola L, Souplet A, Galzin R. 2002. Effects of large-scale habitat variability on condition of demersal exploited fish in the north-western Mediterranean. ICES Journal of Marine Science 59(6):1215-1227 DOI 10.1006/jmsc.2002.1294.

La Mesa G, Molinari A, Gambaccini S, Tunesi L. 2011. Spatial pattern of coastal fish assemblages in different habitats in North-western Mediterranean. Marine Ecology 32(1):104-114 DOI 10.1111/j.1439-0485.2010.00404.x.

Macpherson E, Biagi F, Francour P, García-Rubies A, Harmelin J, Harmelin-Vivien M, Jouvenel JY, Planes S, Vigliola L, Tunesi L. 1997. Mortality of juvenile fishes of the genus Diplodus in protected and unprotected areas in the western Mediterranean Sea. Marine Ecology Progress Series 160:135-147 DOI 10.3354/meps160135.

Pankhurst NW, Munday PL. 2011. Effects of climate change on fish reproduction and early life history stages. Marine and Freshwater Research 62(9):1015-1026 DOI 10.1071/MF10269.

Parsons DM, Middleton C, Spong KT, Mackay G, Smith MD, Buckthought D. 2015. Mechanisms explaining nursery habitat association: how do juvenile snapper (Chrysophrys auratus) benefit from their nursery habitat? PLOS ONE 10(3):e0122137 DOI 10.1371/journal.pone.0122137.

Planes S, Macpherson E, Biagi F, Garcia-Rubies A, Harmelin J, Harmelin-Vivien M, Jouvenel JY, Tunesi L, Vigliola L, Galzin R. 1999. Spatio-temporal variability in growth of juvenile sparid fishes from the Mediterranean littoral zone. Journal of the Marine Biological Association of the United Kingdom 79(1):137-143 DOI 10.1017/S0025315498000150.

Raventós N. 2006. Nest site characteristics and nesting success of the five- spotted wrasse Symphodus roissali in the north-western Mediterranean Sea. Journal of Fish Biology 68(1):305-309 DOI 10.1111/j.0022-1112.2006.00885.x.

Raventos N. 2009. Relationships between adult population size, recruitment, and yearclass strength in a labrid fish in the Mediterranean Sea. Estuarine, Coastal and Shelf Science 85(2):167-172 DOI 10.1016/j.ecss.2009.07.020.

Rueden CT, Schindelin J, Hiner MC, DeZonia BE, Walter AE, Arena ET, Eliceiri KW. 2017. ImageJ2: ImageJ for the next generation of scientific image data. $B M C$ Bioinformatics 18:529 DOI 10.1186/s12859-017-1934-z. 
Ruitton S, Francour P, Boudouresque CF. 2000. Relationships between algae, benthic herbivorous invertebrates and fishes in rocky sublittoral communities of a temperate sea (Mediterranean). Estuarine, Coastal and Shelf Science 50(2):217-230 DOI 10.1006/ecss.1999.0546.

Ruiz-Frau A, Gelcich S, Hendriks IE, Duarte CM, Marbà N. 2017. Current state of seagrass ecosystem services: research and policy integration. Ocean and Coastal Management 149:107-115 DOI 10.1016/j.ocecoaman.2017.10.004.

Sala E, Ballesteros E. 1997. Partitioning of space and food resources by three fish of the genus Diplodus (Sparidae) in a Mediterranean rocky infralittoral ecosystem. Marine Ecology Progress Series 152:273-283 DOI 10.3354/meps152273.

Sala E, Ballesteros E, Dendrinos P, Di Franco A, Ferretti F, Foley D, Fraschetti S, Friedlander A, Garrabou J, Güçlüsoy H, Guidetti P, Halpern BS, Hereu B, Karamanlidis AA, Kizilkaya Z, Macpherson E, Mangialajo L, Mariani S, Micheli F, Pais A, Riser K, Rosenberg AA, Sales M, Selkoe KA, Starr R, Tomas F, Zabala M. 2012. The structure of mediterranean rocky reef ecosystems across environmental and human gradients, and conservation implications. PLOS ONE 7(2):e32742 DOI 10.1371/journal.pone.0032742.

Sala E, Kizilkaya Z, Yildirim D, Ballesteros E. 2011. Alien marine fishes deplete algal biomass in the Eastern Mediterranean. PLOS ONE 6(2):e17356 DOI 10.1371/journal.pone.0017356.

Scharf FS, Manderson JP, Fabrizio MC. 2006. The effects of seafloor habitat complexity on survival of juvenile fishes: species-specific interactions with structural refuge. Journal of Experimental Marine Biology and Ecology 335(2):167-176 DOI 10.1016/j.jembe.2006.03.018.

Schückel S, Sell AF, Kihara TC, Koeppen A, Kröncke I, Reiss H. 2013. Meiofauna as food source for small-sized demersal fish in the southern North Sea. Helgoland Marine Research 67(2):203-218 DOI 10.1007/s10152-012-0316-1.

Seitz RD, Wennhage H, Bergstro U, Lipcius RN, Ysebaert T. 2013. Ecological value of coastal habitats for commercially and ecologically important species. ICES Journal of Marine Science 71:648-665 DOI 10.1093/icesjms/fst152.

Sinopoli M, Chemello R, Vaccaro A, Milazzo M. 2016. Food resource partitioning between two sympatric temperate wrasses. Marine and Freshwater Research 68(12):2324-2335 DOI 10.1071/MF16363.

Sogard SM. 1997. Size-selective mortality in the juvenile stage of teleost fishes: a review. Bulletin of Marine Science 60(3):1129-1157.

Spatharis S, Orfanidis S, Panayotidis P, Tsirtsis G. 2011. Assembly processes in upper subtidal macroalgae: the effect of wave exposure. Estuarine, Coastal and Shelf Science 91(2):298-305 DOI 10.1016/j.ecss.2010.10.032.

Tátrai I, Herzig A. 1995. Effect of habitat structure on the feeding efficiency of young stages of razor fish (Pelecus cultratus (L.)): an experimental approach. Hydrobiologia 299(1):75-81 DOI 10.1007/BF00016887.

Thibaut T, Pinedo S, Torras X, Ballesteros E. 2005. Long-term decline of the populations of Fucales (Cystoseira spp. and Sargassum spp.) in the Albéres coast 
(France, North-western Mediterranean). Marine Pollution Bulletin 50:1472-1489

DOI 10.1016/j.marpolbul.2005.06.014.

Thiriet PD, Di Franco A, Cheminée A, Guidetti P, Bianchimani O, Basthard-Bogain S, Cottalorda JM, Arceo H, Moranta J, Lejeune P, Francour P, Mangialajo L. 2016.

Abundance and diversity of crypto- and necto-benthiccoastal fish are higher in marine forests than in structurally less complex macroalgal assemblages. PLOS ONE 11(10):e0164121 DOI 10.1371/journal.pone.0164121.

Tito de Morais L, Bodiou JY. 1984. Predation on meiofauna by juvenile fish in a Western Mediterranean flatfish nursery ground. Marine Biology 82(2):209-215 DOI 10.1007/BF00394104.

Vázquez-Luis M, Sanchez-Jerez P, Bayle-Sempere JT. 2008. Changes in amphipod (Crustacea) assemblages associated with shallow-water algal habitats invaded by Caulerpa racemosa var. cylindracea in the western Mediterranean Sea. Marine Environmental Research 65(5):416-426 DOI 10.1016/j.marenvres.2008.01.006.

Vergés A, Alcoverro T, Ballesteros E. 2009. Role of fish herbivory in structuring the vertical distribution of canopy algae Cystoseira spp. in the Mediterranean Sea. Marine Ecology Progress Series 375:1-11 DOI 10.3354/meps07778.

Vergés A, Steinberg PD, Hay ME, Poore AGB, Campbell AH, Ballesteros E, Heck KL, Booth DJ, Coleman MA, Feary DA, Figueira W, Langlois T, Marzinelli EM, Mizerek T, Mumby PJ, Nakamura Y, Roughan M, Van Sebille E, Gupta Sen A and, Smale DA, Tomas F, Wernberg T, Wilson SK. 2014a. The tropicalization of temperate marine ecosystems: climate-mediated changes in herbivory and community phase shifts. Proceedings of the Royal Society B 281(201408):1-10 DOI 10.1098/rspb.2014.0846.

Vergés A, Tomas F, Cebrian E, Ballesteros E, Kizilkaya Z, Dendrinos P, Karamanlidis AA, Spiegel D, Sala E. 2014b. Tropical rabbitfish and the deforestation of a warming temperate sea. Journal of Ecology 102(6):1518-1527 DOI 10.1111/1365-2745.12324.

Vigliolat L, Biagi F, Galzin R, Garcia-rubies A, Jouvenel J-Y, Direach-boursiert L Le, Macpherson E. 1998. Spatial and temporal settelment among sparid fishes of the genus Diplodus in among the northwestern Mediterranean. Marine Ecology Progress Series 168:45-56 DOI 10.3354/meps168045.

Woodland RJ, Secor DH, Fabrizio MC, Wilberg MJ. 2012. Comparing the nursery role of inner continental shelf and estuarine habitats for temperate marine fishes. Estuarine, Coastal and Shelf Science 99:61-73 DOI 10.1016/j.ecss.2011.12.019.

Zuur AF, Ieno EN, Elphick CS. 2010. A protocol for data exploration to avoid common statistical problems. Methods in Ecology and Evolution 1(1):3-14 DOI 10.1111/j.2041-210X.2009.00001.x.

Zuur AF, Ieno EN, Walker NJ, Saveliev AA, Smith GM. 2009. Mixed effects models and extensions in ecology with $R$. New York: Springer Verlag. 